\title{
Model Ketimpangan Pembangunan Ekonomi di Indonesia
}

\section{Inequality Model of Economic Development in Indonesia}

\author{
Rini Raharti ${ }^{1)}$, Titi Laras ${ }^{2)}$, Oktavianti Oktavianti ${ }^{3)}$ \\ ${ }^{1,2,3)}$ Fakultas Ekonomi dan Bisnis, Universitas Janabadra, Yogyakarta \\ e-mail korespondensi: riniraharti@janabadra.ac.id
}

\begin{tabular}{|c|c|}
\hline Info $\mathrm{A}$ & \multirow{3}{*}{$\begin{array}{l}\text { Abstrak } \\
\text { Tujuan penelitian ini adalah untuk menganalisis pengaruh pertumbuhan ekonomi } \\
\text { terhadap tingkat ketimpangan pembangunan antar provinsi di Indonesia. Metode } \\
\text { penelitian yang digunakan adalah analisis regresi linear berganda dengan OLS } \\
\text { (ordinary least squares). Hasil analisis menunjukkan bahwa ketimpangan } \\
\text { pembangunan ekonomi antar Propinsi di Indonesia tahun 2005-2019 tergolong } \\
\text { tinggi karena setiap tahunnya mengalami kenaikan yang signifikan, kenyataan } \\
\text { ini sejalan dengan teori Neoklasik. Pertumbuhan ekonomi, tingkat kemiskinan } \\
\text { dan jumlah penduduk berpengaruh positif terhadap ketimpangan pembangunan } \\
\text { ekonomi. Implikasi kebijakan yang dilakukan adalah pemerintah Propinsi di } \\
\text { Indonesia sebaiknya perlu memperhatikan sektor yang menyerap tenaga kerja } \\
\text { sebagai kontribusi pada tingkat pertumbuhan ekonomi dan melakukan } \\
\text { pemberdayaan masyarakat kecil. } \\
\text { Kata Kunci: Ketimpangan Pembangunan, Pertumbuhan Ekonomi, Kemiskinan, } \\
\text { Jumlah Penduduk. }\end{array}$} \\
\hline $\begin{array}{l}\text { Riwayat Artikel: } \\
\text { Diterima: } 17 \text { Juni } 2020 \\
\text { Disetujui: } 18 \text { Juli } 2021 \\
\text { Dipublikasikan: Juli } 2021\end{array}$ & \\
\hline $\begin{array}{l}\text { Nomor DOI } \\
\text { 10.33059/jseb.v12i2.2422 } \\
\text { Cara Mensitasi : } \\
\text { Raharti, R., Laras, T., \& } \\
\text { Oktavianti, O. (2021). Model } \\
\text { ketimpangan pembangunan } \\
\text { ekonomi di Indonesia. Jurnal } \\
\text { Samudra Ekonomi dan Bisnis, } \\
\text { 12(2), 257-270. doi: } \\
\text { 10.33059/jseb. v12i2.2422. }\end{array}$ & \\
\hline & \multirow{3}{*}{$\begin{array}{l}\text { Abstract } \\
\text { The purpose of this study is to analyze the effect of economic growth on the } \\
\text { level of development inequality between provinces in Indonesia. The research } \\
\text { method used is multiple linear regression analysis with OLS (ordinary least } \\
\text { squares). The results of the analysis show that the inequality of economic } \\
\text { development between provinces in Indonesia in 2005-2019 is relatively high } \\
\text { because every year there is a significant increase, this fact is in line with the } \\
\text { Neoclassical theory. Economic growth, poverty rate and population have a } \\
\text { positive effect on inequality in economic development. The policy implication is } \\
\text { that the provincial government in Indonesia should pay attention to sectors that } \\
\text { absorb labor as a contribution to the level of economic growth and empower } \\
\text { small communities. } \\
\text { Keywords: Development Inequality, Economic Growth, Poverty Rate, } \\
\text { Population. }\end{array}$} \\
\hline & \\
\hline $\begin{array}{l}\text { DOI Number: } \\
\text { 10.33059/jseb.v12i2.2422 } \\
\text { How to cite: } \\
\text { Raharti, R., Laras, T., \& } \\
\text { Oktavianti, O. (2021). Model } \\
\text { ketimpangan pembangunan } \\
\text { ekonomi di Indonesia. Jurnal } \\
\text { Samudra Ekonomi dan Bisnis, } \\
\text { 12(2), 257-270. doi: } \\
\text { 10.33059/jseb. v12i2.2422. }\end{array}$ & \\
\hline
\end{tabular}




\section{PENDAHULUAN}

Ketimpangan pembangunan merupakan fenomena yang banyak terjadi dalam aspek perekonomian daerah. Hal tersebut dapat terjadi karena perbedaan kondisi demografi dan sumber daya alam pada daerah masingmasing. Oleh karena itu, daerah mempunyai kemampuan yang berbeda dalam mendorong proses pembangunan ekonomi. Setiap daerah memiliki wilayah maju (developed region) dan wilayah terbelakang (underdeveloped region) (Sjafrizal, 2014; Fahrizal et al., 2019).

Ketimpangan yang terjadi antar wilayah memberi dampak atas tingkat kesejahteraan antar wilayah. Faktor ketimpangan pembangunan antar wilayah dapat juga membawa dampak terhadap pemerintah daerah dalam merumuskan kebijakan arah pembangunan (Andini \& Mandasari, 2017; Prastowo, 2014). Selain itu, masalah-masalah sosial di dalam proses pembangunan daerah relatif tidak ada, sehingga adanya proses pembangunan dapat dimanfaatkan secara merata antar wilayah.

Ketimpangan pembangunan yang terjadi di Indonesia secara makro dipengaruhi oleh adanya kesenjangan dalam alokasi sumber daya, sumberdaya manusia, fisik, teknologi dan kapital. Setiap daerah memiliki karakteristik yang berbeda didalam menghadapi isu ketimpangan pembangunan (Kamaruddin \& Alam, 2018; Khabhibi, 2013). Konsekuensinya, dengan adanya proses pembangunan yang diterapkan di negara-negara maju mengakibatkan ketimpangan antar wilayah menjadi rendah. Pertumbuhan ekonomi merupakan tolok ukur menilai pertumbuhan ekonomi suatu negara sehingga semua harus memahami hakikat serta sumber-sumber pertumbuhan ekonomi.

Pertumbuhan ekonomi merupakan salah satu indikator keberhasilan pembangunan satu negara. Sedangkan pembangunan ekonomi ialah usaha meningkatkan pendapatan per kapita dengan jalan mengolah kekuatan ekonomi potensial menjadi ekonomi riil melalui investasi, penggunaan teknologi modern, peningkatan keterampilan (skill), peningkatan pengetahuan, kemampuan berorganisasi dan manajerial (Heinrich et al., 2020; Firdaus, 2013).

\section{Ketimpangan Pembangunan Ekonomi}

Ketimpangan pembangunan antar wilayah secara absolut maupun relatif antara potensi dan tingkat kesejahteraan masyarakat dapat mengakibatkan permasalahan yang terjadi di daerah. Adanya ketimpangan antar pusat dengan daerah atau antar wilayah satu dengan yang lainnya sudah biasa terjadi. Hal tersebut karena adanya perbedaan sumber daya alam pada tiap daerah (Heinrich et al., 2020; Andini \& Mandasari, 2017).

Teori pertumbuhan ekonomi Neo Klasik menyebutkan bahwa pertumbuhan ekonomi terdiri dari faktor-faktor produksi, yaitu modal, tenaga kerja, dan teknologi (Sukirno, 2017; Azizi, 2020). Pertumbuhan ekonomi yang ada di Indonesia dipengaruhi beberapa komponen seperti investasi dan tenaga kerja. Menurut teori Neo Klasik, pertumbuhan ekonomi juga dipengaruhi oleh pertambahan penyediaan faktor-faktor produksi yakni faktor penduduk, tenaga kerja dan akumulasi modal) serta tingkat kemajuan teknologi. Pembentukan modal akan menghasilkan kemajuan teknologi yang dapat meningkatkan ekonomi produksi dalam skala luas terkait peningkatan spesialisasi. Selain itu, pembentukan modal dapat meningkatkan alat, mesin dan perlengkapan bagi tenaga kerja.

\section{Pertumbuhan Ekonomi}

Pertumbuhan ekonomi adalah beberapa rangkaian kegiatan ekonomi berbagai periode dan menyebabkan pendapatan nasional secara riil berubah. Tingkat pertumbuhan ekonomi suatu negara menunjukkan tingkat persentase kenaikan pendapatan nasional secara riil pada 
suatu tahun tertentu terhadap pendapatan nasional secara riil pada tahun sebelumnya (Sukirno, 2017; Azizi, 2020).

Adanya pertumbuhan ekonomi yang tinggi dan terjadi secara berkelanjutan merupakan fenomena yang harus terwujud bagi keberlanjutan pembangunan ekonomi. Hal tersebut dapat terjadi akibat peningkatan output secara agregat baik barang maupun jasa atau produk domestik bruto (PDB). Menurut tinjauan makro ekonomi, pengertian pertumbuhan ekonomi adalah penambahan produk domestik bruto atau terjadinya penambahan pendapatan nasional (Sohag et al., 2019; Prastowo et al., 2014).

Pertumbuhan ekonomi yang tinggi apabila tidak dibarengi dengan pemerataan pembangunan di seluruh wilayah atau daerah menyebabkan tujuan negara tidak dapat terwujud. Perbedaan potensi daerah-daerah yang ada di Indonesia baik secara geografis maupun sumber daya alamnya, mengakibatkan daerah yang memiliki potensi tinggi akan lebih maju dan makmur dibandingkan dengan daerah lainnya (Bachtiar, 2015; Kamaruddin \& Alam, 2018). Kebijakan pembangunan dilaksanakan dengan tujuan untuk mencapai pertumbuhan ekonomi yang tinggi yakni dengan cara mengoptimalkan potensi dan sumber daya yang tersedia di masing-masing wilayah atau daerah.

Khan et al. (2019) mengemukakan bahwa tolak ukur keberhasilan pembangunan dapat dilihat dari pertumbuhan ekonomi, struktur ekonomi, dan semakin kecilnya ketimpangan pembangunan antar wilayah. Produk domestik regional bruto (PDRB) per kapita daerah adalah salah satu variabel yang digunakan untuk mengukur seberapa besar suatu daerah memiliki tingkat kesejahteraan (Mukhtar et al., 2019; Yacoub, 2012). Artinya, jika PDRB per kapita daerah semakin besar maka semakin baik tingkat kesejahteraan masyarakat; sedangkan, jika semakin kecil nilai PDRB per kapita maka semakin menurun kesejahteraan masyarakat.

Dalam teori fiscal federalism dinyatakan bahwa pertumbuhan ekonomi tercapai dengan desentralisasi fiskal melalui pelaksanaan otonomi daerah (Moges, 2013; PonceRodriguez et al., 2020). Terwujudnya tingkat pertumbuhan ekonomi yang tinggi serta menurunnya angka pengangguran dan kemiskinan juga tidak bisa terlepas dari pengelolaan keuangan daerah yang baik. Sesuai Pedoman Pengelolaan Keuangan Daerah yang diatur dalam Pemendagri Nomor 13 Tahun 2006 Pasal 4 Ayat (1), tata kelola keuangan daerah harus dilakukan dengan tertib, mengikuti aturan perundang-undangan, transparan, ekonomis, efektif, efisien dan ada pertanggungjawaban serta mematuhi azas keadilan, kepatuhan dan bermanfaat untuk masyarakat (Hermawan et al., 2020).

\section{Kemiskinan}

Kemiskinan adalah fenomena yang terjadi dalam masyarakat yang tidak hanya berkaitan dengan tingkat pendapatan yang rendah dan hidup yang serba kekurangan saja, tetapi dapat menyangkut banyak hal seperti tingkat pendidikan yang rendah, rendahnya tingkat kesehatan masyarakat, perlakuan yang tidak adil terhadap hukum, adanya ancaman terhadap tindak kriminal, ketidakmampuan menentukan jalan hidupnya sendiri (Buheji et al., 2020; Ginting, 2015). Kemiskinan merupakan salah satu masalah yang selalu muncul dalam kehidupan masyarakat. Globalisasi di bidang ekonomi mendorong semua negara dapat berperan serta dalam rangka menciptakan pertumbuhan ekonomi yang tinggi. Di sisi lain, juga terjadi ketidakpastian dan terjadi resiko. Negara miskin bisa diukur dengan tingkat pendapatan perkapita rendah dan pertumbuhan penduduknya tinggi yakni lebih dari 2 persen per tahun (Peterson, 2017). 
Permasalahan kemiskinan di Indonesia menjadi hal yang prioritas di bidang ekonomi. Kondisi tersebut dipicu oleh krisis ekonomi yang melanda Indonesia pada tahun 1998 dan jumlah penduduk miskin yang semakin banyak. Dari tahun ke tahun, Pemerintah selalu mencanangkan bagaimana upaya yang dilakukan untuk menanggulangi kemiskinan (Putri \& Almahmudi, 2020; Mukhtar et al., 2019). Namun demikian, faktanya jumlah penduduk miskin yang terdapat di Indonesia tidak mengalami penurunan secara signifikan, meskipun data dari BPS menunjukkan adanya kecenderungan penurunan pada penduduk miskin. Artinya, jumlah penduduk miskin secara kualitatif belum menunjukkan perubahan yang signifikan; melainkan terjadi sebaliknya, yakni fenomena yang semakin memprihatinkan setiap tahunnya.

Xiao (2017) berargumen munculnya kemiskinan yang terus-menerus bermuara pada teori lingkaran setan kemiskinan (vicious cyle of proverty). Kemunculaan kondisi keterbelakangan, ketidaksempurnaan pasar dan rendahnya modal menjadi penyebab rendahnya nilai pendapatan yang diterima masyarakat. Rendahnya tingkat pendapatan akan mengakibatkan tabungan yang rendah, dan selanjutnya menyebabkan investasi juga rendah. Apabila ini diteruskan tanpa ada pemutusan rantai kemiskinan maka akan terus berputar. Oleh karena itu, cara yang dilakukan adalah memperbaiki level keahlian (skill) sumberdaya manusia yang dapat berperan untuk menggerakkan perekonomian daerah.

Saat ini kemiskinan di Indonesia sudah menjadi isu nasional dan pemerintah telah berupaya menurunkan angka kemiskinan dengan berbagai kebijakan yang dilakukan, antara lain kebijakan pada pembangunan infrastruktur penghubung antar wilayah, peningkatan produktifitas pertanian serta sektor perdagangan (Buheji et al., 2020; Ginting, 2015; Firdaus, 2013).
Penyebab lain yang bisa mempengaruhi tingkat kemiskinan adalah pengangguran. Tingkat pendapatan merupakan indikator suatu masyarakat dikatakan makmur ataukah tidak. Level pendapatan masyarakat mencapai dengan baik jika tingkat penggunaan tenaga kerja penuh dapat terwujud. Pengangguran dapat mengurangi tingkatan pendapatan masyarakat, sehingga kemakmuran suatu masyarakat tidak tercapai (Shammi et al., 2020; Menike, 2018; Yacoub, 2012). Apabila tingkat pengangguran di suatu negara mengalami peningkatan, maka menimbulkan dampak buruk pada tingkat kesejahteraan masyarakat dan keberlanjutan ekonomi dalam jangka panjang.

\section{Jumlah Penduduk}

Apabila pertumbuhan penduduk tidak dikendalikan maka dalam jangka panjang sumber daya alam akan habis (Menike, 2018; Preston \& Donaldson, 1986). Akibatnya, muncul wabah penyakit, kelaparan yang meluas, dan berbagai macam persoalan ekonomi masyarakat. Kemiskinan muncul dengan tidak optimalnya tenaga kerja dalam bekerja karena adanya latar belakang ketidakcocokan antara tingkat pendidikan dan pekerjaan yang ditekuni. Dikarenakan tingginya jumlah penduduk yang masuk ke pasar kerja, memaksa para pencari kerja tersebut untuk memperoleh pekerjaan secara instan meskipun tidak sesuai dengan latar belakang pendidikan yang dimiliki karena ketatnya persaingan dalam pasar kerja (Bilan et al., 2020; Conde et al., 2020).

Kemajuan teknologi saat ini yang masuk ke semua lapisan masyarakat, faktanya akan membantu dalam segala bidang. Peralatan-peralatan impor yang digunakan akan meringankan beban pekerjaan manusia, yang dapat menghasilkan barang-barang yang berkualitas. Tetapi dalam hal ini, pemerintah dan masyarakat masih belum puas dengan 
barang-barang impor yang banyak di pasar lokal karena justru menimbulkan masalah baru yang sampai saat ini belum dapat diselesaikan.

Dampak selanjutnya yang muncul di dalam masyarakat yaitu adalah pengangguran. Tingkat pengangguran yang tinggi akan berpengaruh langsung terhadap kemiskinan, tingkat kriminalitas dan masalah-masalah lain yang berkaitan dengan faktor sosial dan politik yang semakin meningkat (Soares et al., 2015; Khan et al., 2020; Misin \& Badivuku-Pantina, 2017). Dengan tingginya jumlah angkatan kerja, arus migrasi yang terus berdatangan, maka menimbulkan permasalahan tenaga kerja yang semakin kompleks. Munculnya masalah pengangguran yang berkepanjangan, maka akan terjadi masalah baru yang kemungkinan besar akan timbul krisis sosial, yang terjadi tidak hanya pada para pencari kerja yang baru lulus sekolah, akan tetapi bisa menimpa para orang tua yang kehilangan pekerjaan dikarenakan banyaknya pabrik dan kantor-kantor yang ditutup. Permasalahan sosial akan mengganggu aktivitas kehidupan seperti makin maraknya tindak kriminalitas, anak-anak yang turun ke jalan, pengamen, pedagang asongan dan lain-lain. Mereka adalah generasi penerus bangsa yang tidak memperoleh pendidikan yang layak dan pembinaan yang baik.

Dari sejumlah problem tersebut, maka dapat dirumuskan permasalahan di dalam artikel ini yaitu seberapa besar tingkat pengaruh dari tingkat pertumbuhan ekonomi, tingkat kemiskinan serta jumlah penduduk terhadap ketimpangan pembangunan ekonomi antar provinsi yang terjadi di Indonesia.

\section{METODE PENELITIAN}

\section{Definisi Operasional Variabel}

Variabel pertama yang dianalisis adalah indeks ketimpangan pembangunan ekonomi.
Indeks ini dihitung menggunakan formula indeks Gini Rasio (Hairani \& Syahputri, 2016; Reza et al., 2019), yakni pendapatan dihitung dengan menggunakan PDRB per kapita atas dasar harga konstan tahun 2000 antar provinsi di Indonesia selama tahun 2005-2019. Indeks ketimpangan pembangunan ekonomi diukur menggunakan parameter bernilai 0 sampai 1 atau $0<\mathrm{VW}<1$.

Variabel kedua adalah laju pertumbuhan ekonomi, yakni perhitungan dari selisih antara tingkat PDRB per tahun tertentu dan PDRB pada tahun sebelumnya (Badan Pusat Statistik, 2009). Parameter yang digunakan untuk menghitung besaran laju pertumbuhan ekonomi adalah dalam satuan persentase.

Variabel ketiga yang dianalisis adalah tingkat kemiskinan, yaitu nilai persentase penduduk yang berada di bawah garis kemiskinan yang terdapat di masing-masing kabupaten/kota di seluruh provinsi di wilayah Indonesia (Badan Pusat Statistik, 2009). Parameter yang dipakai menggunakan dalam satuan persentase.

\section{Sumber Data dan Metode Pengumpulan}

Data yang digunakan seluruhnya adalah data sekunder, yaitu berkenaan dengan variabel-variabel yang dianalisis di dalam penelitian ini yang diperoleh melalui Badan Pusat Statistik Indonesia untuk periode 2005.Q sampai 2019.Q $_{4}$.

Data dikumpulkan dengan cara mendokumentasikan data terkait dengan objek penelitian yang diperoleh dari Badan Pusat Statistik (BPS) maupun dari literatur-literatur yang relevan dengan penelitian ini.

\section{Metode Analisis Data}

Uji Asumsi Klasik

Tahap pertama adalah melakukan uji asumsi klasik, yang meliputi uji normalitas, uji linieritas, uji heteroskedastisitas, uji autokorelasi, dan uji multikolinieritas. 
Uji normalitas bertujuan melihat apakah data yang digunakan dalam penelitian tersebut berdistribusi normal atau tidak (Siregar, 2014; Sugiyono, 2019). Uji ini dilakukan melalui metode chi-square atau $\chi^{2}$ untuk uji goodness of fit distribusi normal meng-gunakan kriteria keputusan bahwa jika nilai JB-statistik $<\chi^{2}$ maka dinyatakan model penelitian ini telah berdistribusi normal.

Uji linearitas bertujuan mengetahui apakah dua variabel yang digunakan dalam penelitian memiliki hubungan yang linier atau tidak, secara signifikan (Riduwan, 2015; Sudjana, 2016). Uji ini pada umumnya digunakan untuk persyaratan dalam analisis korelasi atau regresi linier. Kriteria keputusan bahwa jika nilai probabilitas $(p)>\alpha(0,05)$ maka dinyatakan model penelitian telah memenuhi asumsi linieritas.

Heteroskedastisitas merupakan kondisi dimana varian dari nilai sisa tidak sama antara satu pengamatan dengan pengamatan yang lain. Jika nilai varian dan nilai sisa adalah sama antar pengamatan maka kondisi ini disebut dengan kondisi homoskedastisitas (Siregar, 2014; Sudjana, 2016). Model regresi yang digunakan diharapkan berada pada kondisi homoskedastisitas, bukan kondisi heteroskedastisitas. Uji heterokedastisitas di penelitian ini menggunakan uji BreuschPagan-Godfrey, dimana kriteria keputusan adalah jika nilai Prob. $\mathrm{X}^{2}$ statistik $<\alpha(0.05)$ maka dinyatakan model penelitian tidak memiliki masalah heteroskedastisitas.

Autokorelasi terjadi karena adanya satu observasi yang tersusun dalam rangkaian waktu (seperti pada data runtun waktu atau data time series) atau yang tersusun dalam rangkaian ruang (seperti pada data silang waktu atau data cross-sectional) mengandung residual (kesalahan pengganggu) tidak terbebas dari observasi yang lain (Sugiyono, 2019; Riduwan, 2015). Bila asumsi ini tidak dipenuhi maka bisa mengakibatkan koefisien regresi yang dihasilkan tidak efisien sehingga tidak dapat dilakukan, ataupun menyebabkan uji $t$ dan uji $F$ tidak lagi menjadi valid dan kurang akurat karena taraf keyakinan akan semakin lebar. Uji korelasi dalam penelitian ini menggunakan Breusch-Godfrey Serial Correlation LM-Test dengan kriteria keputusan yaitu jika nilai DW-test berada di daerah $d u<\mathrm{DW}<4-d u$ maka dinyatakan bahwa tidak terdapat masalah autokorelasi dalam model penelitian.

Multikolinearitas merupakan kondisi yang terjadi dengan adanya korelasi variabelvariabel independen diantara satu dengan lainnya. Uji multikolinearitas bertujuan untuk menguji apakah dalam suatu model regresi ditemukan adanya korelasi di antara variabelvariabel independen yang dianalisis (Siregar, 2014; Sugiyono, 2019). Model regresi yang baik seharusnya tidak mengalami multikolinieritas. Kriteria keputusannya adalah jika nilai Tolerance $<0,10$ ataupun nilai VIF (Variance Inflation Factors) >10 maka model penelitian dinyatakan tidak memiliki masalah multikoliniearitas.

\section{Analisis Regresi Berganda}

Tahap berikutnya adalah analisis regresi berganda (multiple linier regression) yang bertujuan menghubungkan variabel $\mathrm{Y}$ dengan dua atau lebih variabel X (Sugiyono, 2019; Sudjana, 2016). Model regresi penelitian ini menganalisis hubungan antara pertumbuhan ekonomi dan tingkat kemiskinan dengan tingkat ketimpangan pembangunan, dengan formulasi:

$$
Y=\beta_{\mathrm{o}}+\beta_{1} X_{1}+\beta_{2} X_{2}+\beta_{3} X_{3}+\varepsilon
$$

dimana $\mathrm{Y}$ yaitu indeks ketimpangan pembangunan ekonomi; $\mathrm{X}_{1}$ adalah pertumbuhan ekonomi; $\mathrm{X}_{2}$ adalah tingkat kemiskinan; $\mathrm{X}_{3}$ adalah jumlah penduduk; $\beta_{0}$ adalah konstanta; $\beta_{1}$ sampai $\beta_{3}$ adalah koefisien regresi dari variabel $\mathrm{X}_{1}$ sampai $\mathrm{X}_{3}$; dan, $\varepsilon$ adalah error 
term. Nilai koefisien regresi menyatakan arah dan besaran pengaruh dari suatu variabel $\mathrm{X}$ terhadap variabel $\mathrm{Y}$.

\section{Uji Hipotesis}

Tahap terakhir adalah melakukan uji hipotesis menggunakan uji $t$ (t-test) dan uji $F$ $(F$-test), serta analisis koefisien determinasi.

Uji $t$ digunakan untuk mengukur apakah suatu variabel independen secara parsial berpengaruh signifikan terhadap variabel dependen (Sudjana, 2016; Sugiyono, 2019). Kriteria keputusan adalah jika nilai Sig. $t$ lebih kecil dari $\alpha(0,05)$ maka dinyatakan variabel independen yang bersangkutan memiliki pengaruh signifikan atas variabel dependen; sebaliknya, jika nilai Sig. $t$ lebih besar dari $\alpha(0,05)$ maka dinyatakan bahwa variabel independen itu memiliki pengaruh yang tidak signifikan atas variabel dependen.

Uji $F$ digunakan untuk menilai apakah semua variabel independen yang dicakup dalam model penelitian secara simultan berpengaruh secara signifikan atau tidak signifikan atas variabel dependen (Sudjana, 2016; Sugiyono, 2019). Kriteria keputusan yang digunakan adalah jika nilai Sig. $F$ lebih kecil dari $\alpha(0,05)$ maka dinyatakan bahwa semua variabel independen yang dianalisis memiliki pengaruh simultan yang signifikan atas variabel dependen; sebaliknya, jika nilai Sig. $F$ lebih besar dari $\alpha(0,05)$ maka dinyatakan bahwa semua variabel independen yang dianalisis memiliki pengaruh simultan yang tidak signifikan atas variabel dependen.

Koefisien determinasi bertujuan untuk mengukur seberapa jauh kemampuan model regresi dalam menjelaskan variasi yang terjadi atas variabel dependen (Sugiyono, 2019; Siregar, 2014). Angka koefisien determinasi berada dalam kisaran nol dan satu $\left(0<\mathrm{R}^{2}<\right.$ 1). Nilai $R^{2}$ yang kecil atau mendekati 0 (nol) berarti kemampuan variabel independen dalam menjelaskan variabel dependen sangat terbatas atau kecil; sebaliknya, apabila $\mathrm{R}^{2}$ mendekati nilai 1 (satu) berarti variabel independen yang dianalisis dianggap mampu memprediksi variasi dari variabel dependen.

\section{HASIL ANALISIS}

\section{Hasil Uji Asumsi Klasik}

Hasil pengolahan data berdasarkan uji normalitas diperoleh nilai Jarque-Bera (JBstatistik) sebesar 2,278362, serta nilai probability sebesar 0,328954. Pada nilai JBstatistik tersebut dengan $d f$ sebesar 217 maka diperoleh nilai $\chi^{2}$-tabel sebesar 97.948,86. Dikarenakan nilai JB-statistik (2.278362) < $\chi^{2}$-tabel (97.948.86), maka berdasarkan hasil uji normalitas dinyatakan model dalam penelitian ini telah berdistribusi normal.

Berikutnya, Tabel 1 menunjukkan hasil perhitungan berdasarkan uji linieritas bahwa diperoleh nilai F-statistik sebesar 1,232789 dengan probabilitas ( $p$ ) sebesar 0,0015. Karena nilai probabilitas $(p)<\alpha(0,05)$ maka dapat dinyatakan bahwa model penelitian ini telah memenuhi asumsi linieritas.

Tabel 2 menunjukkan hasil pengujian heteroskedastisitas memakai Breusch-PaganGodfrey test, dimana jika nilai prob. Fstatistik sebesar 0,0654 dengan $\alpha$ sebesar 0,05 maka diperoleh nilai prob. $\chi^{2}$-statistik sebesar 0,0379. Dikarenakan nilai prob. $\chi^{2}$-statistik < $\alpha(0,05)$ maka dinyatakan bahwa model yang diestimasikan di dalam penelitian ini tidak mengalami masalah heteroskedastisitas.

Pada hasil uji autokorelasi, diperoleh nilai DW sebesar 1,547836, $\mathrm{n}>60 \mathrm{k}<2$. Dengan demikian, diperoleh nilai $\mathrm{Dl}=1,3093$ dan $\mathrm{Du}=1,5736$, sehingga hasil diperoleh adalah: dl $<\mathrm{du}<\mathrm{dw}<4-\mathrm{du}<4-\mathrm{dl}$, atau $1,3093<1,5736<1,547836<1,1769<$ 1,7323. Hasil perhitungan uji Durbin Watson menunjukkan nilai $D W$-test sebesar 1,547836 berada di daerah antara du $<$ DW $<4$-du, maka bisa dinyatakan tidak terdapat masalah autokorelasi dalam model penelitian ini. 
Tabel 1. Hasil Uji Linieritas

\begin{tabular}{lccc}
\hline & Value & $d f$ & Probability \\
\hline$t$-statistik & 3,511109 & 28 & 0,0015 \\
$F$-statistik & 1,232789 & $(1,28)$ & 0,0015 \\
Likelihood ratio & 1,167484 & 1 & 0,0006 \\
\hline
\end{tabular}

Sumber: Data diolah, 2021.

Tabel 2. Hasil Uji Heteroskedastisitas

\begin{tabular}{llcl}
\hline F-statistik & 3,788294 & Prob. F (2,29) & 0,0654 \\
Obs*R-squared & 6,628580 & Prob. Chi-Square (2) & 0,0379 \\
Scaled explained SS & 7,346007 & Prob. Chi-Square (2) & 0,0254 \\
\hline
\end{tabular}

Sumber: Data diolah, 2021.

Tabel 3. Hasil Uji Multikolinieritas

\begin{tabular}{cccc}
\hline Variable & Coefficient variance & Uncentered VIF & Centered VIF \\
\hline X1 & $2.90 \mathrm{E}-05$ & 1.921751 & 1.045553 \\
X2 & 0.001334 & 57.36368 & 1.045553 \\
C & $1.77 \mathrm{E}+10$ & 55.26181 & NA \\
\hline
\end{tabular}

Sumber: Data diolah, 2021.

Tabel 4. Hasil Analisis Regresi dan Uji Hipotesis

\begin{tabular}{llrc}
\hline \multicolumn{1}{c}{ Variabel } & Koefisien & \multicolumn{1}{c}{$t$} & Prob. \\
\hline$C$ & 2.893 .963 & 18,26628 & 0,0000 \\
$\mathrm{X}_{1}$ & $-0,038755$ & $-3,993858$ & 0,0037 \\
$\mathrm{X}_{2}$ & 0,178839 & 3,936399 & 0,0049 \\
$\mathrm{X}_{3}$ & 0.254846 & 3,173661 & 0,0261 \\
\hline$F$-hitung & $=$ & 29,35538 & \\
Sig.F & $=$ & 0,000007 & \\
$R$-Squared & $=$ & 0,7893 & \\
Adjusted R-Squared & $=$ & 0,7152 & \\
$D$ W-Stat & $=$ & 0,625 & \\
$\mathrm{~N}$ & $=$ & 60 & \\
\hline
\end{tabular}

Sumber: Data diolah, 2021.

Berdasarkan hasil uji multikolinieritas yang dirangkum dalam Tabel 3 diperoleh nilai VIF adalah sebesar kurang dari 10 dan nilai Tolerance kurang dari 0,10. Dengan demikian bisa dinyatakan bahwa model yang digunakan dalam penelitian ini tidak mengalami masalah multikolinieritas.
Hasil Analisis Regresi Berganda

Rangkuman hasil analisis data dalam Tabel 4 secara matematis menunjukkan formula regresi linier berganda bagi model penelitian ini adalah:

$$
\begin{aligned}
Y= & 2.893 .963-0,038755 X_{1}+0,178839 X_{2} \\
& +0,254846 X_{3}
\end{aligned}
$$


Model regresi berganda yang diperoleh untuk penelitian ini menunjukkan pengaruh dari variabel independen $X_{1}$ memiliki arah yang negatif terhadap variabel dependen (Y). Artinya, apabila terjadi arah kenaikan pada variabel pertumbuhan ekonomi, dengan asumsi bahwa variabel-variabel independen yang lain tidak mengalami perubahan atau bernilai tetap, maka terjadi perubahan yang menurun atas besaran dari ketimpangan pembangunan ekonomi. Sebaliknya, apabila terjadi penurunan pada variabel pertumbuhan ekonomi, dengan asumsi bahwa variabelvariabel independen yang lain bernilai tetap, maka terjadi kenaikan atas besaran dari ketimpangan pembangunan ekonomi.

Di sisi lain, model regresi berganda tersebut menunjukkan pengaruh dari variabel independen $\mathrm{X}_{2}$ dan $\mathrm{X}_{3}$ memiliki arah yang positif terhadap variabel dependen (Y). Artinya, apabila terjadi arah kenaikan pada salah satu antara variabel tingkat kemiskinan atau variabel jumlah penduduk, dengan asumsi bahwa variabel-variabel independen yang lain tidak mengalami perubahan atau bernilai tetap, maka terjadi kenaikan atas besaran ketimpangan pembangunan ekonomi. Sebaliknya, apabila terjadi penurunan pada variabel tingkat kemiskinan atau variabel jumlah penduduk, dengan asumsi bahwa variabel-variabel independen lain bernilai tetap, maka terjadi penurunan atas besaran dari ketimpangan pembangunan ekonomi.

Model regresi berganda tersebut juga menunjukkan variabel $X_{3}\left(\beta_{3}=0,254846\right)$ memiliki nilai koefisien regresi paling besar dibandingkan variabel $X_{1}\left(\beta_{1}=-0,038755\right)$ dan variabel $X_{2}\left(\beta_{2}=0,178839\right)$. Dengan demikian, hasil ini menyatakan bahwa jumlah penduduk mempunyai pengaruh dominan terhadap ketimpangan pembangunan ekonomi ketimbang pertumbuhan ekonomi dan tingkat kemiskinan.

\section{Hasil Uji Hipotesis}

Hasil uji terkait hubungan parsial antara variaabel independen dan variabel dependen juga dirangkum dalam Tabel 4. Berdasarkan tabel tersebut diidentifikasi bahwa nilai Sig. $t$ untuk masing-masing variabel independen $\left(X_{1}=0,0037 ; X_{2}=0,0049 ; X_{3}=0,0261\right)$ adalah lebih kecil dari $\alpha(0,05)$. Dengan demikian, dinyatakan bahwa variabel-variabel independen yang dianalisis dalam penelitian ini (yaitu: pertumbuhan ekonomi, kemiskinan, dan jumlah penduduk) memiliki pengaruh signifikan atas ketimpangan pembangunan ekonomi sebagai variabel dependen.

Berdasarkan hasil uji simultan dalam Tabel 4, diidentifikasi nilai Sig. $F$ sebesar 0,000007 . Karena nilai tersebut lebih kecil dari $\alpha(0,05)$ maka dinyatakan variabelvariabel independen yang dianalisis dalam penelitian ini (yaitu: pertumbuhan ekonomi, kemiskinan, dan jumlah penduduk) secara simultan memiliki pengaruh signifikan atas ketimpangan pembangunan ekonomi sebagai variabel dependen.

Terakhir, berdasarkan Tabel 4 diperoleh nilai koefisien determinasi (Adjusted $R$ Squared) dengan metode OLS sebesar 0,7152. Hasil ini memiliki arti bahwa variasi atas ketimpangan pembangunan ekonomi selaku variabel dependen (Y) dapat dijelaskan oleh variabel-variabel independen yang dicakup dalam model penelitian ini sebesar $71,52 \%$; sedangkan sisanya sebesar 28,48\% menunjukkan masih adanya variabel-variabel lain yang tidak dicakup di dalam model ini namun terindikasi ikut mempengaruhi perubahan dari variabel dependen.

\section{Pembahasan}

Hasil penelitian ini menunjukkan bahwa pertumbuhan ekonomi mempunyai pengaruh negatif dan signifikan terhadap ketimpangan pembangunan ekonomi. Hasil ini menyatakan bahwa apabila Indonesia mampu mengalami 
peningkatan pertumbuhan ekonomi maka terjadi penurunan atas derajat ketimpangan pembangunan ekonomi nasional; sebaliknya, jika Indonesia malah mengalami penurunan pertumbuhan ekonomi maka dapat terjadi kenaikan atas ketimpangan pembangunan ekonomi nasional.

Pertumbuhan ekonomi merupakan suatu indikator keberhasilan suatu negara dalam pencapaian pembangunan yang lebih baik, dimana bila pertumbuhan ekonomi tersebut setiap tahunnya mengalami peningkatan yang signifikan maka dapatlah dikatakan bahwa roda pembangunan negara tersebut sangat baik (Heinrich et al., 2020; Sohag et al., 2019; Kamaruddin \& Alam, 2018). Kondisi saat ini yang terindentifikasi pembangunan banyak terpusat dikota-kota besar khususnya di Pulau Jawa sedangkan di kawasan Indonesia Bagian Timur dinilai masih kurang berkembang. Hal ini berarti terjadi tingkat pembangunan yang tidak merata antar daerah yang selanjutnya kondisi ini menurut para ahli menyebabkan semakin besarnya ketimpangan ekonomi nasional (Khan et al., 2019; PonceRodriguez et al., 2020; Firdaus, 2013). Kondisi ini yang harus direspon pemerintah baik yang berada di pusat maupun daerah untuk menetapkan bentuk-bentuk kebijakan yang bisa memberi stimulus bagi peningkatan pertumbuhan ekonomi nasional.

Hasil penelitian kedua menyatakan bahwa tingkat kemiskinan memiliki pengaruh positif dan signifikan terhadap ketimpangan pembangunan ekonomi di Indonesia. Artinya, semakin rendah tingkat kemiskinan yang dicapai maka semakin rendah pula level ketimpangan pembangunan ekonomi nasional yang terjadi. Sebaliknya, jika tingkat kemiskinan bisa ditekan menjadi rendah maka akan mendorong penurunan ketimpangan pembangunan ekonomi yang terjadi dan bisa mendorong capaian pembangunan ekonomi yang semakin baik.
Studi milik Pangkiro et al. (2016) memperoleh nilai koefisien elastisitas dari pengaruh tingkat kemiskinan atas disparitas ekonomi sebesar 9,5 yang signifikan pada $\alpha$ sebesar 0,03 atau 3\%. Hasil ini menyatakan bahwa peningkatan tingkat kemiskinan akan mempertinggi ketimpangan pembangunan ekonomi yang terjadi di suatu wilayah. Kondisi saat ini dinilai menunjukkan bahwa Indonesia telah relatif berhasil meningkatkan angka lamanya hidup, tingkat pengetahuan/ pendidikan serta kelayakan standar hidup. Rendahnya tingkat kemiskinan menunjukkan bahwa secara nasional, kesehatan semakin baik, pendidikan semakin tinggi serta standar hidup layak semakin tinggi (Buheji et al., 2020; Shammi et al., 2020; Menike, 2018; Xiao, 2017). Sejumlah kondisi ini dapat memberi konklusi akhir bahwa ketimpangan pembangunan ekonomi nasional semakin berkurang.

Hasil penelitian yang ketiga menyatakan jumlah penduduk memiliki pengaruh negatif signifikan atas ketimpangan pembangunan ekonomi. Hasil ini mengidentifikasi bahwa semakin banyak jumlah penduduk maka memperbesar probabilitas tingkat ketimpangan pembangunan ekonomi nasional. Namun demikian, semakin sedikit jumlah penduduk secara relatif maka memperkecil probabilitas tingkat ketimpangan pembangunan ekonomi nasional yang terjadi. Hal ini karena dinilai bahwa semakin banyak jumlah penduduk di suatu negara maka memperbesar probabilitas meningkatnya pengangguran di negara itu, yang bisa mendorong peningkatan jumlah kemiskinan (Soares et al., 2015; Khan et al., 2020; Misin \& Badivuku-Pantina, 2017). Penduduk miskin lebih banyak menghabiskan tenaga dan waktu yang ada untuk memenuhi kebutuhan dasar. Mereka tidak tertarik untuk melibatkan diri pada aktivitas-aktivitas yang tidak secara langsung berkaitan dengan pemenuhan kebutuhan dasar diri mereka. 
Pemerintah seharusnya mengupayakan tindakan agar masyarakat Indonesia tidak terpuruk di dalam kondisi kemiskinan. Begitupun untuk tahun-tahun kedepannya, dengan harapan agar pemerintah mempunyai kesadaran akan masyarakat kecil, karena di daerah-daerah terpencil masih banyak warga yang mengeluh akibat tidak adanya mata pencaharian dan penghasilan yang cukup, jadi setidaknya memberi mereka peluang usaha ataupun pekerjaan yang memadai (Chen \& Haynes, 2017; Menike, 2018; Bilan et al., 2020; Conde et al., 2020). Program ini tentunya akan membantu masyarakat untuk memenuhi kebutuhan hidupnya, di samping juga berpengaruh terhadap masyarakat kecil untuk kelangsungan hidupnya. Program pemerintah ini juga tentunya akan sangat membantu sehingga masyarakat tidak akan terbebani dengan kemiskinan yang menimpa mereka dalam fenomena tersebut, tentunya bisa mengurangi besaran nilai ketimpangan pembangunan ekonomi yang ada.

\section{SIMPULAN}

Hasil penelitian berbasis indeks Gini rasio ini menyimpulkan beberapa hal terkait dengan kondisi perekonomian di Indonesia selama periode 2005-2019.

Kesimpulan pertama, level ketimpangan pembangunan ekonomi antar provinsi di Indonesia tahun 2005 -2019 tergolong tinggi, dikarenakan setiap tahun mengalami kenaikan yang signifikan. Kenyataan ini sejalan dengan teori Neo Klasik yang diuraikan terdahulu. Terlihat juga bahwa indeks ketimpangan pembangunan ekonomi di Indonesia tersebut cenderung meningkat antar provinsi di Indonesia.

Kesimpulan kedua, tingkat pertumbuhan ekonomi berpengaruh positif terhadap ketimpangan pembangunan ekonomi. Hal ini dapat diartikan, jika pertumbuhan ekonomi mengalami peningkatan, maka ketimpangan pembangunan ekonomi juga akan mengalami peningkatan, demikian juga sebaliknya.

Kesimpulan ketiga, tingkat kemiskinan berpengaruh positif dan signifikan terhadap ketimpangan pembangunan ekonomi. Hal ini dapat diartikan, jika tingkat kemiskinan mengalami penurunan, maka ketimpangan pembangunan ekonomi juga akan mengalami penurunan, demikian juga sebaliknya.

Kesimpulan terakhir, jumlah Penduduk berpengaruh positif terhadap ketimpangan pembangunan ekonomi. Hal ini bisa diartikan bahwa jika jumlah penduduk mengalami peningkatan, maka ketimpangan pembangunan ekonomi juga mengalami peningkatan; demikian juga sebaliknya.

\section{REFERENSI}

Andiny, P., \& Mandasari, P. (2017). Analisis pertumbuhan ekonomi dan kemiskinan terhadap ketimpangan di Provinsi Aceh. JENSI (Jurnal Penelitian Ekonomi Akuntansi), 1(2), 196-210. Retrieved from http://jurnal.unsam.ac.id/index. php/jensi/article/view/412.

Azizi, S. S. (2020). Impact of remittances on financial development. Journal of Economic Studies, 47(3), 476-477. doi: 10.1108/JES-01-2019-0045.

Bachtiar, A. (2015). Pemetaan potensi pertumbuhan ekonomi daerah dengan menggunakan tipologi Klassen di Surabaya dan sekitarnya. Jurnal Ilmu Ekonomi Pembangunan, 6(1), 1-11. Retrieved from http://eprints.upnjatim. ac.id/6677/.

Badan Pusat Statistik. (2009). Pedoman praktis penghitungan produk domestik regional bruto kabupaten/kota, Tata cara penghitungan menurut penggunaan. Badan Pusat Statistik.

Badan Pusat Statistik. (2020). Kemiskinan dan ketimpangan. Retrieved from https://www.bps.go.id/subject/23/kemis kinan-dan-ketimpangan.html. 
Bilan, Y., Mishchuk, H., Roshchyk, I., \& Kmecova, I. (2020). An analysis of intellectual potential and its impact on the social and economic development of European countries. Journal of Competitiveness, 12(1), 22-38. doi: 10.7441/joc.2020.01.02.

Buheji, M., Cunha, K. C., Beka, G., Mavrić, B., de Souza, Y. L. C., Silva, S. S. C., Hanafi, M., \& Yein, T. C. (2020). The extent of COVID-19 pandemic socioeconomic impact on global poverty: A global integrative multidisciplinary review. American Journal of Economics, 10(4), 213-224. doi: 10.5923/j.economics.20201004.02.

Chen, Z., \& Haynes, K. E. (2017) Impact of high-speed rail on regional economic disparity in China. Journal of Transport Geography, 65(August), 80-91. doi: 10.1016/j.jtrangeo.2017.08.003.

Conde, J. M. P., Ortiz, C. C., \& Álvarez, J. C. M.. (2020). Comparison of the determinants of the potential of economic development of the municipalities of Andalusia with population range 15.000-20.000 Inhabitants between the years 2007 and 2012. Revista De Estudios Regionales, 118, 115-147. Retrieved from https:// idus.us.es/bitstream/handle/11441/1150 51/1/articulo\%20idus.pdf?sequence $=1$.

Fahrizal, Sarfiah, S. N., \& Juliprijanto, W. (2019). Analisis ketimpangan ekonomi Provinsi Jawa Tengah Tahun 20082017. DINAMIC: Directory Journal of Economic, 1(4), 399-417. doi: 10.31002/dinamic.v1i4.803.

Firdaus, M. (2013). Ketimpangan pembangunan antar wilayah di Indonesia: Fakta dan strategi inisiatif. Orasi Ilmiah. Fakultas Ekonomi dan Manajemen Institut Pertanian Bogor.

Ginting, A. M. (2015). Pengaruh ketimpangan pembangunan antarwilayah terhadap kemiskinan di Indonesia 2004-2013. Kajian, 20(1), 45-58. doi: 10.22212/ kajian.v20i1.569.
Hairani, P. R. S., \& Syahputri, A. R. (2016). Analisis ketimpangan ekonomi dan pengaruhnya terhadap tingkat kriminalitas di Propinsi Sumatera Utara. Ekonomikawan, 16(1), 56-76. doi: 10.30596\%2Fekonomikawan.v16i1. 1018.

Heinrich, T., Yang, J., \& Dai, S. (2020). Growth, development, and structural change at the firm level: The example of the PR China. Working Papers on East Asian Studies, No 128/2021. Retrieved from https://arxiv.org/pdf/ 2012.14503.pdf.

Hermawan, A. W., Sinaga, H. D. P., \& Barus, L. B. (2020). Legal reconstruction of tax-sharing funds in Indonesia: towards the progressive and democratic tax function. Proceedings of the $2 n d$ International Conference of Law, Government and Social Justice (ICOLGAS 2020), 153-159. doi: 10.2991/assehr.k.201209.279.

Kamaruddin, C. A., \& Alam, A. (2018). Analisis potensi sektor unggulan dan pemetaan kemiskinan masyarakat di wilayah Maminasata Sulawesi Selatan. Jurnal Administrare: Jurnal Pemikiran Ilmiah dan Pendidikan Administrasi Perkantoran, 5(2), 85-98. doi: 10.26858/ja.v5i2.7886.

Khabhibi, A. (2013). Ekonomi pembangunan: Teori masalah dan kebijakan (Edisi Ketiga). UPP AMP YKPN.

Khan, M. I., Iqbal, A., Zaman, S. I., \& Wajidi, F. (2020). Economic development and unemployment: A missing link. Market Forces, 15(2), 81-100. doi: 10.51153/mf.v15i2.463.

Khan, S. A. R., Jian, C., Zhang, Y., Golpîra, H., Kumar, A., \& Sharif, A. (2019). Environmental, social and economic growth indicators spur logistics performance: From the perspective of South Asian association for regional cooperation countries. Journal of Cleaner Production, 214, 1011-1023. doi: 10.1016/j.jclepro.2018.12.322. 
Menike, H. R. A. (2018). A literature review on population growth and economic development. International Journal of Humanities Social Sciences and Education (IJHSSE). 5(5), 67-74. doi: 10.20431/2349-0381.0505009

Misin, S., \& Badivuku-Pantina, M. (2017). The effect of economic growth in relation to unemployment. Journal of Economics and Economic Education Research, 18(2), 1-9. Retrieved from https://www.abacademies.org/articles/t he-effect-of-economic-growth-inrelation-to-unemployment-6778.html.

Moges, A. G. (2013). Fiscal federalism in theory and practice. Ethiopian $e$ Journal for Research and Innovation Foresight, 5(1), 6-32. Retrieved from https://journals.bdu.edu.et/index.php/ee jrif4/article/viewFile/281/371.

Mukhtar, R., Wijaya, A., \& Roy, J. (2019). Pengaruh pertumbuhan ekonomi dan tingkat pengangguran serta indeks pembangunan manusia terhadap kemiskinan di Kota Samarinda. Jurnal Ilmu Ekonomi Mulawarman, 4(3). doi: 10.29264/jiem.v4i3.5936.

Peterson, E. W. F. (2017). The role of population in economic growth. SAGE Open, 7(4), 1-15. doi: 10.1177/2158244 017736094.

Ponce-Rodríguez, R. A., Hankla, C. R., \& Martinez-Vazquez, J. (2020). The politics of fiscal federalism: Building a stronger decentralization theorem. Journal of Theoretical Politics, 32(4), 605-639. doi: 10.1177/0951629820956 287.

Prastowo, Y., dkk. (2014). Ketimpangan pembangunan Indonesia dari berbagai aspek. Infid.

Preston, S. H., \& Donaldson, P. (1986). Population growth and economic development. Asia-Pacific Population Journal, 1(2), 3-12. Retrieved from https://www.unescap.org/sites/default/fi les/APPJ-Vol-1-No-2.pdf.
Putri, N. T., \& Almahmudi, A. (2020). Analisis ketimpangan pembangunan di Provinsi Bengkulu (Telaah posisi 3 kabupaten induk). Convergence: The Journal of Economic Development, 2(1), 70-90. doi:10.33369/convergencejep.v2i1.12075.

Reza, M., Jamal, A., \& Zulham, T. (2019). Analisis ketimpangan pembangunan dan distribusi pendapatan wilayah di Provinsi Aceh. Jurnal Ekonomi dan Kebijakan Publik Indonesia, 6(1), 1732. doi: 10.24815/ekapi.v6i1.14256.

Riduwan. (2015). Dasar-dasar statistika. Alfabeta.

Shammi, M., Bodrud-Doza, M., Islam, A. R. M. T., \& Rahman, M. M. (2021). Strategic assessment of COVID-19 pandemic in Bangladesh: Comparative lockdown scenario analysis, public perception, and management for sustainability. Environment, Development and Sustainability, 23, 6148-6191. doi: 10.1007/s10668020-00867-y.

Siregar, S. (2014). Statistik parametrik untuk penelitian kuantitatif: Dilengkapi dengan perhitungan manual dan aplikasi SPSS versi 17 (Edisi 1). Bumi Aksara.

Sjafrizal. (2014). Perencanaan pembangunan dalam era otonomi. PT. RajaGrafindo Persada.

Soares, A., Nurpratiwi, R., \& Makmur, M. (2015). Peranan pemerintah daerah dalam perencanaan pembangunan daerah. JISIP: Jurnal Ilmu Sosial dan Ilmu Politik, 4(2), doi: 10.33366/jisip. v4i2.102.

Sohag, K., Taşkın, F. D., \& Malik, M. N. (2019). Green economic growth, cleaner energy and militarization: Evidence from Turkey. Resources Policy, 63(October), No. 101407. doi: 10.1016/j.resourpol.2019.101407.

Sudjana. (2016). Metode statistika. Taristo.

Sugiyono. (2019). Metode penelitian kuantitatif, kualitatif, dan $R \& D$ (Edisi kedua). Alfabeta. 
Sukirno, S. (2017). Ekonomi pembangunan: Proses, masalah, dan dasar kebijakan. Kencana.

Xiao, A. H. (2017). Exploring social interactions between chinese immigrants and corruption in Nigeria. in Adeniran A., Ikuteyijo L. (eds). Africa Now! Emerging Issues and Alternative Perspectives. Palgrave Macmillan. doi: 10.1007/978-3-319-62443-3_9.
Yacoub, Y. (2012). Pengaruh tingkat pengangguran terhadap tingkat kemiskinan kabupaten/kota di Provinsi Kalimantan Barat. Jurnal Eksos, 8(3), 176-185. Retrieved from https://riset. polnep.ac.id/bo/upload/penelitian/pener bitan_jurnal/06-eksos\%204\%20yarlina $\% 20$ okt12.pdf. 